\title{
AKTIVITAS TABIR SURYA DAUN MIANA (Coleus atropurpureus L. Benth) SECARA IN VITRO
}

\author{
Mufti Shofia Amrillah, Rolan Rusli, Jaka Fadraersada \\ Laboratorium Penelitian dan Pengembangan FARMAKA TROPIS, Fakultas Farmasi, \\ Universitas Mulawarman, Samarinda, Kalimantan Timur \\ Email : ofiyofiyofiy@gmail.com
}

\begin{abstract}
Plants that have good antioxidant activity could potentially be used as a sunscreen. Miana leaves (Coleus atropurpureus $\mathrm{L}$. Benth.) has good antioxidant activity. In vitro sunscreen activity ethanol extract and ethyl acetate fraction of miana leaf using UV-Vis spectrophotometer at a wavelength of 290-375 $\mathrm{nm}$. The best sunscreen category of ethanol extract and ethyl acetate fraction of miana leaves is a sunblock category with each concentration are 200 ppm and 100 ppm.
\end{abstract}

Key words: Coleus atropurpureus L. Benth., sunscreen, \%Te, \% Tp.

\begin{abstract}
ABSTRAK
Tanaman yang memiliki aktivitas antioksidan yang baik berpotensi digunakan sebagai tabir surya. Daun miana (Coleus atropurpureus L. Benth.) memiliki aktivitas antioksidan yang baik. Uji aktivitas tabir surya ekstrak etanol dan fraksi etil asetat daun miana dilakukan secara in vitro menggunakan spektrofotometer UV Vis pada panjang gelombang 290-375 $\mathrm{nm}$. Kategori terbaik tabir surya ekstrak etanol dan fraksi etilasetat daun miana adalah kategori sunblock dengan konsentrasi masing-masing adalah 200 ppm dan 100 ppm.
\end{abstract}

Kata kunci: Coleus atropurpureus L. Benth., tabir surya, \%Te, \% Tp.

\section{PENDAHULUAN}

Indonesia dikenal sebagai negara tropis, dimana pengaruh sinar matahari sangat besar terhadap kehidupan makhluk hidup (Malulidia, 2010). Sinar matahari mengandung sinar inframerah dan sinar ultraviolet memiliki pengaruh kimiawi. Dengan bantuan sinar ultraviolet, provitamin D dalam kulit diubah menjadi vitamin D (Kusumadewi, 2002). Efek merugikan yang dapat ditimbulkan oleh radiasi ultraviolet pada kulit adalah terjadinya kerusakan epidermis yang biasa disebut dengan sengatan surya, pigmentasi, pengkerutan kulit, penuaan kulit dini, dan pada penyinaran yang lama dibawah terik matahari dapat mengakibatkan perubahan pada jaringan pengikat dalam lapisan korneum (Agustin, 2013).

Pada jangka panjang paparan sinar UV terutama UV B dapat menyebabkan melanoma. Melanoma maligna merupakan tumor ganas sel melanosit dengan pertumbuhan agresif dan resisten terhadap terapi. Sel melanosit merupakan sel normal yang terdapat pada lapisan basal epidermis kulit. Sel ini berfungsi untuk melindungi tubuh dari paparan sinar matahari 
terutama sinar UV yang dapat merusak komposisi DNA sel normal. Paparan sinar UV B serta terjadinya mutasi gen yang berperan dalam proliferasi dan apoptosis sel, dapat meningkatkan pertumbuhan sel melanosit dan menghasilkan tumor, baik tumor jinak (nevus melanositik) atau tumor ganas (melanoma maligna) (Tjandra, 2009).

Melanoma maligna merupakan tumor ganas kulit yang paling banyak menimbulkan kematian di Amerika Serikat dan Eropa. Di Australia, insiden dan mortalitas masih terus meningkat. Di Indonesia menurut data histopatologis, kanker kulit merupakan kanker ketiga tersering dan melanoma maligna menyebabkan $1 \%$ sampai $2 \%$ dari semua kematian akibat kanker (Tjandra, 2009).

Tabir surya merupakan bahanbahan kosmetik yang secara fisik atau kimia dapat menghambat penetrasi sinar UV ke dalam kulit. Ada pula tabir surya alami di alam, misalnya senyawa fenolik yang terdapat dalam tumbuhan dan berfungsi melindungi jaringan tanaman terhadap kerusakan akibat radiasi sinar matahari. Senyawa fenolik khususnya golongan flavonoid mempunyai potensi sebagai tabir surya karena adanya gugus kromofor yang mampu menyerap sinar UV baik UV A maupun UV B sehingga mengurangi intensitasnya pada kulit (Shovyana, 2013).

Berbagai bahan alam dapat digunakan sebagai bahan tabir surya, antara lain rimpang kencur, daun teh, rimpang temugiring dan rimpang bangle. Minyak atsiri rimpang kencur (Kaempferia galanga L.) mengandung etil sinamat dan etil $p$-metoksisinamat yang berfungsi sebagai penyaring sinar UV, minyak daun kayu manis (Oleum cinnamomi) mengandung turunan asam sinamat, daun teh (Camellia sinensis L. Kuntze) mengandung senyawa polifenol yang berfungsi sebagai antioksidan (Fatmawati, 2006). Sedangkan daun miana (Coleus atropurpureus L. Benth.) mengandung flavonoid dengan aktivitas antioksidan yang cukup tinggi dimana $\mathrm{IC}_{50}$ yang dimiliki pada ekstrak etanolnya yaitu 48,04 ppm dan pada fraksi etil asetat 22,98 ppm (Sari, 2013).

Tanaman dari genus Coleus dari keluarga Lamiaceae atau Labiatae banyak digunakan dalam pengobatan tradisional sebagai antimikroba, antioksidan, antiseptik, dan aktivitas farmakologi lainnya. Daun rebusan Coleus atropurpureus L. Benth. diindikasikan untuk pengobatan tradisional bronkitis, wasir, antioksidan, dan TBC (Ahmad, 2014). Corak, bentuk, dan warna miana beranekaragam, tetapi yang berkhasiat obat adalah daun yang berwarna merah kecoklatan (Dalimartha, 2007). Salah satu senyawa yang ada pada tanaman ini adalah flavonoid (Hutapea, 2000). Berdasarkan uraian di atas maka dilakukan uji aktivitas tabir surya pada daun miana.

\section{METODOLOGI}

\section{Bahan dan Alat}

Bahan yang digunakan pada penelitian ini yaitu daun miana, etanol 95\%, n-heksana, etil asetat, air suling, dan etanol PA.

Peralatan yang digunakan pada penelitian ini yaitu timbangan analitik, rotary evaporator, corong pisah, botol vial, kuvet kuarsa, mikropipet, spektrofotometer UV Vis (HALO DB20S), labu ukur, pipet ukur, dan pipet volume.

\section{Prosedur Pengujian}

Sampel Daun Miana yang diambil dari Kecamatan Samarinda Seberang Kelurahan Mangkupalas, kota Samarinda dimaserasi dan difraksinasi untuk memperoleh ekstrak etanol dan fraksi etil asetat daun miana. Ekstrak etanol dan fraksi etil asetat daun miana yang diperoleh dibuat dalam 5 seri konsetrasi yaitu $75,100,150,200$, dan 250 ppm (untuk ekstrak etanol) dan 50, 
75, 100, 125, dan $150 \mathrm{ppm}$ (untuk fraksi etil asetat). Masing-masing konsetrasi uji diukur absorbansinya menggunakan spektrofotometer (HALO DB-20S) pada panjang gelombang 290-375 $\mathrm{nm}$ dengan kenaikan $5 \mathrm{~nm}$. Hasil pengukuran absorbansi diolah dengan menggunakan persamaan 1, dan dilanjutkan dengan persamaan 2 dan 3 .

Keterangan:

$$
\mathrm{A}=-\log \mathrm{T} \quad(\text { Persamaan } 1)
$$

A = absorbansi

$\mathrm{T}=$ nilai transmisi

Data $\mathrm{T}$ (transmisi) yang diperoleh dapat diolah dengan menggunakan persamaan Balsam (1972) untuk memperoleh \% Te dan \% Tp.

$$
\begin{gathered}
\% \text { Transmisi eritema }(\mathrm{Te})=\frac{\Sigma \mathrm{Ee}}{\Sigma \mathrm{Fe}}= \\
\frac{\Sigma(\mathrm{T} \times \mathrm{Fe})}{\Sigma \mathrm{Fe}} \quad(\text { Persamaan } 2)
\end{gathered}
$$

$$
\begin{gathered}
\% \text { Transmisi pigmentasi }(\mathrm{Tp})=\frac{\Sigma \mathrm{Ep}}{\Sigma \mathrm{Fp}}= \\
\frac{\Sigma(\mathrm{T} \times \mathrm{Fp})}{\Sigma \mathrm{Fp}} \quad(\text { Persamaan } 3)
\end{gathered}
$$

Keterangan:

$\mathrm{T}=$ Transmisi

$\mathrm{Fe}=$ Fluks eritema pada panjang gelombang tertentu

$\mathrm{Ee}=$ Banyaknya fluks eritema yang diteruskan oleh tabir surya

$\mathrm{Fp}=$ Fluks pigmentasi pada panjang gelombang tertentu

Ep = Banyaknya fluks pigmentasi yang diteruskan oleh tabir surya

\section{HASIL DAN PEMBAHASAN}

Hasil pengamatan persen transmisi (\% T) ekstrak etanol daun miana pada konsentrasi 75, 100, 150, 200, dan $250 \mathrm{ppm}$ disajikan dalam tabel 1 serta serapan fraksi etil asetat daun miana pada konsentrasi 50, 75, 100, 125, dan 150 ppm disajikan dalam tabel 2.

Tabel 1. Nilai \%T Ekstrak Etanol daun Miana Sebagai Tabir Surya

\begin{tabular}{cccccc}
\hline \multirow{2}{*}{$\lambda(\mathrm{nm})$} & $75 \mathrm{ppm}$ & $100 \mathrm{ppm}$ & $150 \mathrm{ppm}$ & $200 \mathrm{ppm}$ & $250 \mathrm{ppm}$ \\
\cline { 2 - 6 } & 18,8669 & 10,0300 & 3,8080 & 0,6551 & 0,4419 \\
292,5 & 19,4850 & 10,4882 & 4,0672 & 0,7223 & 0,4928 \\
302,5 & 19,6020 & 10,5682 & 4,0992 & 0,7273 & 0,4958 \\
307,5 & 18,8669 & 10,0300 & 3,7993 & 0,6587 & 0,4480 \\
312,5 & 17,5509 & 9,1264 & 3,3113 & 0,5830 & 0,3690 \\
317,5 & 16,2069 & 8,1470 & 2,8333 & 0,4443 & 0,2967 \\
322,5 & 15,2300 & 7,4765 & 2,5194 & 0,3808 & 0,2529 \\
327,5 & 14,9520 & 7,2996 & 2,4266 & 0,3617 & 0,2425 \\
332,5 & 15,2862 & 7,5509 & 2,5527 & 0,3906 & 0,2669 \\
337,5 & 16,3305 & 8,2794 & 2,9040 & 0,4653 & 0,3234 \\
342,5 & 18,6337 & 10,0462 & 3,8256 & 0,7323 & 0,5420 \\
347,5 & 21,1495 & 11,9867 & 4,8674 & 1,0046 & 0,7464 \\
352,5 & 24,9632 & 14,8936 & 6,6635 & 1,5265 & 1,1811 \\
357,5 & 29,8538 & 19,4984 & 20,5258 & 2,5509 & 2,0621 \\
362,5 & 36,3915 & 25,7217 & 14,1808 & 4,6132 & 3,8459 \\
367,5 & 44,1266 & 33,5506 & 20,8113 & 8,0854 & 7,0958 \\
372,5 & 51,4873 & 41,8794 & 28,6220 & 12,9718 & 11,8768 \\
\hline
\end{tabular}


Tabel 2. Nilai \%T Fraksi Etil Asetat Daun Miana Sebagai Tabir Surya

\begin{tabular}{cccccc}
\hline \multirow{2}{*}{$\lambda(\mathrm{nm})$} & $50 \mathrm{ppm}$ & $75 \mathrm{ppm}$ & $100 \mathrm{ppm}$ & $125 \mathrm{ppm}$ & $150 \mathrm{ppm}$ \\
\cline { 2 - 6 } & 4,3222 & 1,2993 & 0,2425 & 0,1000 & 0,1037 \\
292,5 & 4,7830 & 1,4870 & 0,2882 & 0,1007 & 0,1119 \\
302,5 & 5,0003 & 1,5693 & 0,3088 & 0,1000 & 0,1154 \\
307,5 & 4,9204 & 1,5311 & 0,2985 & 0,1000 & 0,1169 \\
312,5 & 4,5572 & 1,3740 & 0,2630 & 0,1000 & 0,1119 \\
317,5 & 4,0832 & 1,1921 & 0,2173 & 0,1000 & 0,1057 \\
322,5 & 3,7757 & 1,0747 & 0,1875 & 0,1000 & 0,1045 \\
327,5 & 3,7958 & 1,0757 & 0,1865 & 0,1000 & 0,1057 \\
332,5 & 4,2005 & 1,2388 & 0,2198 & 0,1005 & 0,1102 \\
337,5 & 5,1015 & 1,6032 & 0,3034 & 0,1228 & 0,1202 \\
342,5 & 6,8438 & 2,3807 & 0,5408 & 0,1556 & 0,1715 \\
347,5 & 9,3907 & 3,6450 & 0,9198 & 0,2963 & 0,2301 \\
352,5 & 13,1432 & 5,8036 & 1,7326 & 0,6561 & 0,4204 \\
357,5 & 18,4629 & 9,2897 & 3,3497 & 1,5195 & 0,9579 \\
362,5 & 25,4097 & 14,6454 & 7,9068 & 3,4119 & 2,2439 \\
367,5 & 33,4965 & 21,6920 & 11,3501 & 6,8549 & 4,9397 \\
372,5 & 41,5241 & 29,5121 & 17,6076 & 14,8936 & 9,1348 \\
\hline
\end{tabular}

Sinar UV yang berasal spektorofotometer UV Vis digambarkan sebagai sinar UV dari sinar matahari yang merupakan salah satu radiasi elektromagtnetik. Jika senyawa dikenai suatu radiasi elektromagnetik pada frekuensi yang sesuai sehingga energi tersebut ditingkatkan ke level yang lebih tinggi, maka terjadi peristiwa penyerapan (absorpsi) energi oleh molekul (Gandjar, 2011). Banyaknya sinar yang diabsorbsi pada panjang gelombang tertentu sebanding dengan banyaknya molekul yang menyerap sinar. Sinar yang diteruskan merupakan cahaya yang tidak diabsorbsi oleh sampel sehingga menghasilkan nilai $\mathrm{T}$ (transmisi). Sehingga, semakin kecil nilai $\mathrm{T}$ menunjukkan bahwa sinar yang diteruskan semakin kecil atau semakin banyak sinar yang diserap oleh sampel.

Efektivitas sediaan tabir surya dapat dilakukan dengan metode penentuan $\%$ transmisi eritema (\% Te) dan $\%$ transmisi pigmentasi (\% $\mathrm{Tp}$ ). Transmisi merupakan persentase sinar yang diteruskan oleh sediaan tabir surya. Dari nilai serapan (A) yang diperoleh kemudian dihitung nilai serapan untuk 1 $\mathrm{g} / \mathrm{L}$, selanjutnya ditentukan nilai transmisi (T) $1 \mathrm{~g} / \mathrm{L}$ dengan menggunakan persamaan 1. Nilai transmisi eritema yaitu jumlah energi sinar ultraviolet penyebab eritema pada panjang gelombang 290-375 nm. Nilai transmisi eritema didapat dari persamaan 2 .

Hasil perhitungan \% Te dan \% Tp ekstrak dan fraksi etil asetat daun miana disajikan pada Tabel 3. 
Tabel 3. Hasil pegujian aktivitas tabir surya ekstrak dan fraksi etil asetat daun miana

\begin{tabular}{cccc}
\hline Konsentrasi $(\mathrm{ppm})$ & \% & \% & Kategori \\
\hline Ekstrak etanol & & & \\
\hline 75 & 19,7407 & 19,3003 & - \\
100 & 10,8785 & 10,3486 & Suntan standar \\
150 & 4,8837 & 4,0136 & Proteksi ekstra \\
200 & 0,9393 & 0,7089 & Sunblock \\
250 & 0,7001 & 0,4843 & Sunblock \\
\hline Fraksi etil asett & & & \\
\hline 50 & 6,4012 & 5,0393 & Suntan standar \\
75 & 2,4439 & 1,5799 & Proteksi ekstra \\
100 & 0,8353 & 0,3779 & Sunblock \\
125 & 0,3158 & 0,1097 & Sunblock \\
150 & 0,3092 & 0,1203 & Sunblock \\
\hline
\end{tabular}

Senyawa yang berpotensi menunjukkan aktivitas tabir surya yang baik adalah bahan yang dapat menghasilkan nilai \%Te ataupun \%Tp yang kecil dengan konsentrasi optimum. Hal ini menujukkan bahwa, senyawa tersebut dapat menghalangi sinar UV melewati kulit sehingga mencegah terjadinya kerusakan kulit akibat sinar matahari. Nilai \%Te dan \%Tp tersebut dapat diklasifikasikan ke dalam beberapa kategori tabir surya yaitu fast tanning, suntan standar, proteksi ekstra, dan sunblock. Kategori yang memiliki nilai $\% \mathrm{Te}$ dan \% Tp paling kecil yaitu sunblock.

Sediaan tabir surya dapat dikategorikan sebagai sunblock yaitu sediaan yang dapat menyerap hampir semua sinar UV-B dan sinar UV-A apabila memiliki persentase transmisi eritema $1 \%$ dan persentase transmisi pigmentasi 3-40\%, jika persentase transmisi eritema 6-18\% dan persentase transmisi pigmentasi 45-86\% dikategorikan sebagai Suntan atau dapat dikatakan suatu bahan yang menyerap sebagian besar sinar UV-B dan menyerap sedikit sinar UV-A (Cumpelik, 1972).

Hasil pengamatan menunjukkan bahwa ekstrak etanol daun miana mencapai kategori suntan standar pada konsentrasi 100 ppm, kemudian dapat mencapai kategori proteksi ekstra pada konsentrasi 150 ppm, dan mencapai kategori sunblock pada konsentrasi 200 ppm. Sedangkan fraksi etil asetat dapat mencapai kategori suntan standar pada konsentrasi $50 \mathrm{ppm}$, kemudian mencapai kategori proteki ekstra pada konsentrasi 75 ppm, dan mencapai kategori sunblock pada konsentrasi 100 ppm. Hal ini menunjukkan bahwa fraksi etil asetat daun miana memiliki aktivitas tabir surya yang lebih tinggi dibandingkan ekstrak etanolnya.

Daun miana yang memiliki aktivitas antioksidan yang tinggi juga dapat menunjukkan aktivitas tabir surya yang baik pula. Senyawa bahan alam baru-baru ini dipertimbangkan memiliki potensial sebagai sumber aktivitas tabir surya karena absorbansi yang mereka miliki dalam rentang sinar UV. Terdapat fakta yang kuat bahwa kerusakan DNA 
akibat sinar UV menyebabkan flavonoid dan senyawa fenolik lain sebagai penyerap sinar UV terakumulasi pada jaringan kulit tanaman (Ebrahimzadeh, 2013). Di antara berbagi macam senyawa fenolik, flavonoid kemungkinan merupakan kelompok senyawa yang terpenting. Disamping melawan radikal yang diinduksi oleh sinar UV, flavonoid mungkin memberikan efek perlindungan untuk melawan radiasi UV dengan berperan sebagai penyerap sinar UV yang kuat (Raimundo, 2013). Daun miana memiliki antosianin yang merupakan salah satu kelompok senyawa flavonoid yang berperan memberikan warna ungu pada tanaman. Senyawa antosianin yang terdapat pada daun miana adalah senyawa pelargonidin-3-rutinosida dan sianidin-3O-glukosida (Hardiyanti, 2013). Kemungkinan senyawa flavonoid dan polifenol daun miana banyak terekstraksi dalam fraksi etil asetat daun miana. Oleh karena itu, konsentrasi sunblock yang paling baik dimiliki oleh fraksi etil asetat daun miana.

\section{KESIMPULAN}

Ekstrak etanol dan fraksi
etilasetat daun miana (Coleus atropurpureus L. Benth.) memiliki aktivitas tabir surya yang baik. Kategori tabir surya ekstrak etanol daun miana adalah kategori suntan standar, proteksi ekstra, dan sunblock dengan konsentrasi untuk masing-masing kategori berturutturut adalah 100, 150, dan 200 ppm. Sedangkan fraksi etilasetat daun miana dapat mencapai kategori suntan standar, proteksi ekstra, dan sunblock dengan konsentrasi untuk masing-masing kategori berturut-turut adalah 50, 75, dan 100 ppm.

\section{DAFTAR PUSTAKA}

1. Maulidia, Syifa Octa. 2010. Uji Efektifitas dan Fotostabilitas Krim Ekstrak Etanol 70\% Teh Hitam (Camellia sinensis L.) sebagai Tabir Surya Secara In Vitro. Program Studi
Kedokteran dan Ilmu Kesehatan UIN: Jakarta.

2. Kusumadewi. 2002. Perawatan dan tata Rias Wajah Wanita Usia 40+. PT. Gramedia Pustaka Utama: Jakarta.

3. Agustin, Rini dkk. 2013. Formulasi Krim Tabir Surya dari Kombinasi Etil p-Metoksisinamat dengan Katekin. Prosiding Seminar Nasional Perkembangan Terkini Sains Farmasi dan Klinik III. ISSN: 2339-2592.

4. Tjandra, Lusiana. 2009. Ekspresi Protein Cyclin D1 pada Melanoma Maligna dan Nevus Melanositik. Program Pascasarjana Universitas Airlangga Surabaya.

5. Shovyana, Hidayatul Hana dan Zulkarnain, Karim. 2013. Stabilitas Fisik dan Aktivitas Krim W/O Ekstrak Etanolik Buah Mahkota Dewa (Phaleria macrocarpha (scheff.) Boerl,) Sebagai Tabir Surya. Traditional Medica Journal. 18. (2). 109-117.

6. Fatmawati, Aisyah dkk. 2006. Uji Aktivitas Ekstrak Etanol Temugiring (Curcuma heyneana Val.) Sebagai bahan Tabir Surya. Majalah Farmasi dan Farmakologi. 10. (2). 46-53.

7. Sari, Devi Dewinta. 2013. Uji aktivitas Antioksidan Ekstrak Daun Miana (Coleus Atropurpuresus L. Benth.) terhadap DPPH (1,1Diphenyl-2-Picrylhidrazyl.

Universitas Mulawarman: Samarinda.

8. Ahmad, Ahyar and Muh. Nasrum Massi. 2014. The Antituberculosis Rifampicin is Activated by 2',5'Dimethyl Benzopelargonolactone from The Leaf Coleus atropurpureus L., Benth. International Journal of Pharma and Bio Science. 5. (1). (B) 758-764.

9. Dalimartha, S. 2007. Atlas Tumbuhan Obat Indonesia Jilid I. Trubus Agriwidya: Jakarta.

10. Hutapea, Johnny.,dkk. 2000. Inventaris Tanaman Obat Indonesia (I) Jilid 1. Depkes RI: Jakarta. 
11. Balsam, M. S. \& Sagarin, E. (Eds.). 1972. Cosmetics: Science and Technology $2^{\text {nd }}$ Ed., Vols. 1-3. Interscience Publishers, Inc: New York.

12. Gandjar, Ibnu Gholib dan Abdul Rohman. 2011. Kimia Farmasi Analisis. Pustaka Pelajar: Yogyakarta.

13. Cumpelik, Boris M. 1972. Analytical Procedures and Evaluation of Sunscreen. Journal of the Society of Cosmetic Chemists. 23. 333-345.

14. Ebrahimzadeh, Mohammad Ali, Reza Enayatifard, Masoumeh Khalili, dkk. 2013. Correlation between Sun Protection Factor and Antioxidant Activity, Phenol and Flavonoid
Content of Some Medical Plants. Iranian Journal of Pharmaceutycal Reasearch. 13. (3). 1041-1047.

15. Raimundo Goncalves de Oliveira Junior, Camila de Souza Araujo, dkk. 2013. In Vitro Antioxidant and Photoprotective Activities of Dried Extract from Neoglaziovia variegata (Bromeliaceae). Journal of Apllied Phamaceutycal Science. 3. (1). 122127.

16. Hardiyanti, Yuniar dkk. 2013. Ekstraksi dan Uji Antioksidan senyawa Antosianin dari Miana (Coleus scutellarioides L. (Benth)) Serta Aplikasi pada Minuman. Jurnal Kimia Unand. 2. (2). 44-50. 